\title{
DETERMINAN KEBERHASILAN LELANG HAK TANGGUNGAN PADA KPKNL MANADO TAHUN 2015-2016
}

\author{
Josep May Hardi Ginting, Vekie A Rumate, Debby Ch. Rotinsulu \\ Fakultas Ekonomi dan Binis, Magister Ilmu Ekonomi dan Bisnis \\ Universitas Sam Ratulangi, Manado
}

\begin{abstract}
ABSTRAK
Penelitian ini bertujuan untuk mengetahui faktor-faktor yang mempengaruhi keberhasilan lelang hak tanggungan di KPKNL Manado. Lelang hak tanggungan berhasil jika objek lelang laku terjual. Penelitian ini penting dilakukan karena keberhasilan lelang hak tanggungan di KPKNL Manado relatif rendah sementara lelang hak tanggungan merupakan lelang yang dominan di KPKNL Manado. Data yang diteliti berupa risalah lelang eksekusi hak tanggungan di KPKNL Manado dari tahun 2015 sampai dengan September 2016 dengan mengambil sampel sebanyak 63 transaksi lelang. Untuk menganalisis digunakan analisis regresi berganda binari dengan model logit.

Hasil penelitian menunjukkan bahwa faktor aksesibilitas berpengaruh positif dan signifikan terhadap keberhasilan lelang, faktor deviasi nilai limit dengan nilai likuidasi, faktor lokasi dan faktor kondisi kekosongan objek lelang berpengaruh negatif dan signifikan terhadap keberhasilan lelang eksekusi hak tanggungan di KPKNL Manado.
\end{abstract}

Kata kunci: Keberhasilan Lelang Hak Tanggungan, Keberhasilan Lelang, Analisis Regresi Berganda Binari Model Logit, Objek Lelang

\begin{abstract}
The aim of this research is to determine the factors which affects the successful of mortgage auction in KPKNL Manado. Auction of mortgage auction successful if the object sold. This research is important because the success of the mortgage auction in Manado KPKNL relatively low while the auction of mortgage is the dominant auction KPKNL Manado. The Data examined in the form of the minutes of the auction execution KPKNL security rights in Manado from 2015 until September 2016 by taking a sample of 63 transactions auction. To analyze the use of multiple regression analysis with the binary logit model.

The results showed that the accessibility factor positive and significant impact on the success of the auction, the deviation factor liquidation value of the limit value, location factors and factors auction conditions of the object vacancy significant negative effect on the success of the mortgage auction in KPKNL Manado.
\end{abstract}

Keywords: Successful Mortgage Auction,The Success of the auction, Multiple Regression Analysis Binary Logit Model, The Object of The Auction 


\section{Latar Belakang}

\section{PENDAHULUAN}

Pembangunan sering diartikan sebagai suatu proses usaha untuk peningkatan kesejahtraan dan kemakmuran hidup manusia secara terus menerus dengan usaha-usaha yang memanfaatkan sumber daya. Kegiatan pembangunan ekonomi tidak akan berjalan lancar tanpa didukung oleh sektor perbankan sebagai perantara dalam menghimpun dan menyalurkan dana masyarakat. Dalam menjalankan usahanya, bank menghadapi banyak risiko usaha, salah satunya adalah permasalahan kredit macet. Salah satu bentuk penyelesaikan kredit macet adalah dengan menjual barang jaminan untuk pelunasan hutang dengan cara pelelangan dengan menggunakan dasar Undang Undang Nomor 4 tahun 1996 tentang Hak Tanggungan(UUHT).

Lelang adalah penjualan barang yang terbuka untuk umum dengan penawaran harga secara tertulis dan/atau lisan yang semakin meningkat atau menurun untuk mencapai harga tertinggi, yang didahului dengan pengumuman lelang (Keputusan Menteri Keuangan Republik Indonesia Nomor: 27PMK.06/2016). Pelaksanaan lelang dilakukan dengan penawaran lisan dengan harga naik-naik atau penawaran secara tertutup dengan dasar pelepasan harga lelang adalah harga limit lelang. Kompetisi penawaran dengan naik-naik(ascending) dapat menaikkan harga lelang sampai dengan harga yang maksimal.

Lelang sebagai salah satu instrumen dalam penjualan di pasar mempunyai fungsi privat dan fungsi publik. Salah satu fungsi publik lelang adalah untuk mengumpulkan penerimaan negara dalam bentuk Bea Lelang dan Pajak Penghasilan (PPh) Pasal 25 serta Bea Perolehan Hak Atas Tanah dan Bangunan (BPHTB) untuk pemerintah daerah. BPHTB merupakan salah satu sumber Pendapatan Asli Daerah (PAD) yang diharapkan dapat membiayai penyelenggaraan pemerintahan daerah dan pembangunan daerah. Di Kota Manado penerimaan BPHTB memberikan kontribusi yang besar terhadap PAD Kota Manado dibandingkan dengan penerimaan daerah lainnya. Berdasarkan dari data BPS pada tahun 2013 kontribusi BPHTB terhadap PAD Kota Mando adalah 20,77\%, Tahun 2014 seebsar 14,46\% dan Tahun 2015 sebesar $14,36 \%$.

Pelaksanaan lelang eksekusi harus dilaksanakan oleh Kantor Pelayanan Kekayaan Negara dan Lelang (KPKNL). KPKNL merupakan Institusi di bawah Kementerian Keuangan Republik Indonesia, Direktorat Jenderal Kekayaan Negara. Untuk wilayah Provinsi Sulawesi Utara dilayani oleh KPKNL Manado. Banyaknya perbankan yang ada di Indonesia dan khususnya yang ada di Provinsi Sulawesi Utara menyebabkan jumlah frekuensi lelang Hak Tanggungan yang diadakan di KPKNL Manado tinggi. Dari sebanyak 1.279 frekuensi pelaksanaan lelang Pasal 6 UUHT KPKNL Manado pada tahun 2015 hanya 64 frekuensi yang laku atau 5\%. Sedangkan pada tahun 2016 (s.d September 2016) dari 694 frekunsi lelang hanya 52 frekuensi yang laku atau 7,49\%.

\section{Rumusan Masalah}

Sedikitnya jumlah lelang yang berhasil(laku) menimbulkan masalah penelitian yang menarik untuk dikaji yang dapat dirumuskan sebagai berikut : faktor-faktor apa yang mempengaruhi keberhasilan lelang eksekusi pasal 6 Undang-Undang Hak Tanggungan di KPKNL Manado?(sehingga tingkat keberhasilan lelangnya masih sangat rendah)

\section{Tujuan Penelitian}

Tujuan penelitian ini adalah untuk mengetahui faktor-faktor yang berpengaruh terhadap hasil lelang eksekusi pasal 6 UUHT pada KPKNL Manado.

\section{Manfaat penelitian}

Manfaat yang diharapkan dari penelitian ini adalah:

1. Memberikan gambaran mengenai faktor-faktor yang mempengaruhi keberhasilan lelang eksekusi pasal 6 UUHT;

2. Memberikan solusi untuk meningkatkan tingkat keberhasilan lelang;

3. Bagi KPKNL Manado dan DJKN pada umumnya dan kepada Perbankan sebagai Debitur dalam rangka meningkatkan tingkat keberhasilan pelaksanaan lelang yang berasal dari eksekusi pasal 6 UUHT; 
4. Bagi ilmu pengetahuan dapat menambah wawasan dan referensi dalam hal lelang Indonesia.

\section{TINJAUAN PUSTAKA}

\section{Teori Pembangunan Ekonomi dan Pembangunan Ekonomi Daerah}

Pembangunan merupakan proses transformasi yang dalam perjalanan waktu ditandai oleh perubahan structural yaitu perubahan pada landasan kegiatan ekonomi maupun pada kerangka susunan ekonomi masyarakat yang bersangkutan (Sumitro, 1998:73). Pembangunan bukanlah semata fenomena ekonomi, pembangunan harus dipahami sebagai salah satu proses yang berdimensi jarak yaitu melibatkan perubahanperubahan besar dalam struktur sosial, seluruh rakyat dan kelembagaan nasional serta percepatan pembangunan ekonomi, pengangguran, ketidakmerataan, kemiskinan absolute (Todaro, 1999:29).

W.W. Rostow dalam bukunya The Stages of Economic Growth (1960), mengartikan pembangunan jika sudut pandang nya dalam arti proses, diartikan sebagai modernisasi yakni pergerakan dari masyarakat pertanian berbudaya tradisional ke arah ekonomi yang berfokus pada rasional, industri, dan jasa. Menurut Arsyad, (1999:108109) bahwa pembangunan ekonomi daerah adalah suatu proses dimana pemerintah daerah dan masyarakat mengelola sumber daya-sumber daya yang ada dan membentuk suatu pola kemitraan anatara pemerintah daerah dan sector swasta untuk menciptakan suatu lapangan kerja baru dan merangsang perkembangan kegiatan ekonomi(pertumbuhan ekonomi) diwilayah tersebut. Pertumbuhan ekonomi daerah adalah pertambahan pendapatan masyarakat yang terjadi di wilayah tersebut, yaitu kenaikan seluruh nilai tambah (added value) yang terjadi di wilayah tersebut. Pertambahan pendapatan itu diukur dalam nilai riil, artinya dinyatakan dalam harga konstan (Tarigan, 2004).

\section{Lelang di Indonesia}

Penjualan umum melalui lelang diatur di dalam Peraturan Lelang (Vendu Reglement) stb. 1908 Nomor 189 dan Instruksi Lelang (Vendu Instructie) stb. 1908 Nomor 190, berikut peraturan pelaksanaannya. Dalam Peraturan Menteri Keuangan Nomor 27PMK.06/2016, Lelang adalah penjualan barang yang terbuka untuk umum dengan penawaran harga secara tertulis dan/atau lisan yang semakin meningkat atau menurun untuk mencapai harga tertinggi, yang didahului dengan pengumuman lelang.

Lelang sebagai salah satu cara penjualan mempunyai fungsi privat dan fungsi publik. Lelang memiliki fungsi privat karena lelang merupakan institusi pasar yang mempertemukan penjual dan pembeli, maka lelang turut berfungsi untuk memperlancar arus lalu lintas perdagangan barang. Sedangkan lelang mempunyai fungsi publik karena lelang merupakan instrument pemerintah untuk pengamanan asset yang dimiliki/dikuasi oleh negara untuk meningkatkan efesiensi dan tata tertib administrasi pengelolaannya, Lelang mendukung badan-badan peradilan dalam mewujudkan fungsi pengadilan untuk semua penjualan eksekusi, Lelang mengumpulkan penerimaan negara dalam bentuk Bea Lelang, Pajak Penghasilan dan Bea Perolehan Hak Atas Tanah dan Bangunan

\section{Teori Lokasi}

Salah satu karakteristik fisik properti adalah lokasi. Lokasi merupakan faktor yang paling kuat pengaruhnya terhadap nilai suatu properti karena menentukan kemudahan letak properti untuk dicapai. Menurut Fanning (2005:47) menyatakan bahwa masalah lokasi ini juga berhubungan dengan aksesibilitas yang diukur dengan kemudahan menuju pusat tertentu dan kondisi lingkungan yang berkaitan dengan keadaan sekitar tapak. 
Teori lokasi berkaitan erat dengan teori perkembangan wilayah yang dikemukaan oleh E.W. Burgess dalam teori konsentrik (Yunus 2000:15) yang menyatakan bahwa perkembangan suatu kota akan mengikuti pola lingkaran konsentrik, dimana suatu kota akan terdiri dari zona-zona yang konsentris dan masing-masing zona ini sekaligus mencerminkan tipe penggunaan lahan yang berbeda. Perkembangan daerah cenderung meluas di sekitarnya sejalan dengan laju pertumbuhan ekonomi. Interpretasi teori ini secara ekonomi menekankan bahwa semakin dekat dengan pusat kota (central bussiness distrik/CBD) semakin mahal harga tanahnya.

\section{Faktor-faktor yang mempengaruhi keberhasilan lelang}

Aksesiblitas dalam penelitian ini adalah lebar jalan tempat lokasi objek. Aksesibilitas akan baik bila jalannya lebar dan aksesibilitas kurang bila jalannya sempit. Akses jalan ternyata juga sangat mempengaruhi nilai properti. Hal ini dapat dipahami karena orang akan cenderung memilih properti yang memiliki akses jalan yang lebih mudah (lebar).

Deviasi nilai limit dengan nilai likuidasi. Nilai limit yang dimaksud dalam penelitian ini adalah nilai minimal yang ditetapkan oleh penjual untuk dicapai dalam suatu pelelangan sebagai dasar untuk mengesahkan pemenang lelang. Nilai likuidasi yang dimaksud untuk penjualan lelang seringkali digunakan dan memiliki arti yang sama dengan nilai jual paksa. Nilai likuidasi tersebut diperoleh dari nilai tanah dan bangunan yang dikurangkan dengan resiko lelang (resiko pengosongan, resiko penguasaan dan resiko penjualan melalui lelang). Property yang akan dilelang dengan kondisi yang kosong, tidak ditempati oleh pemilik asal, penyewa atau pihak ketiga akan meningkatkan probabilitas keberhasilan lelang.

\section{Kerangka Pemikiran Penelitian}

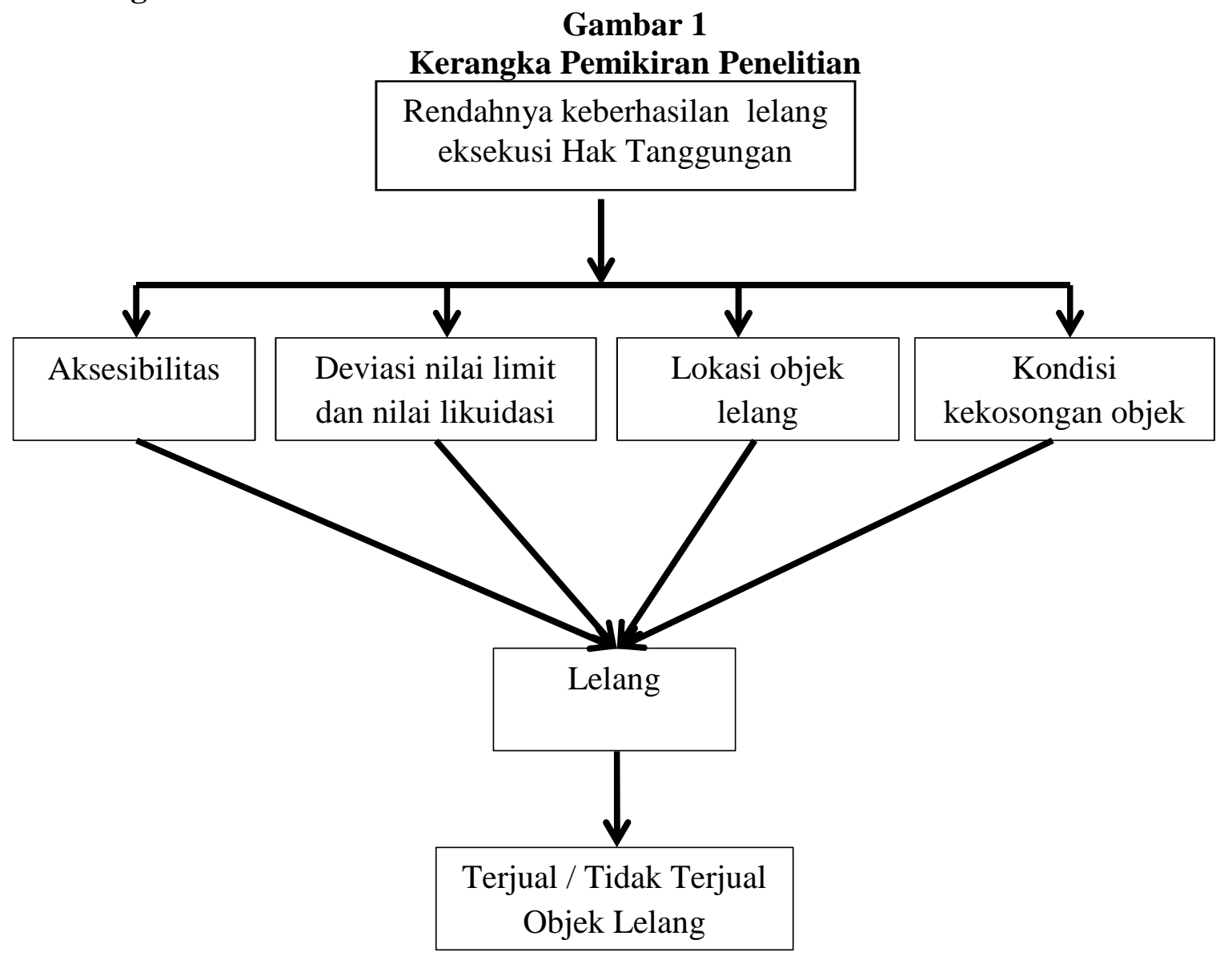




\section{METODE PENELITIAN}

\section{Data dan Sumber Data}

Data yang digunakan dalam penelitian ini adalah data sekunder dan dilengkapi dengan data primer. Data sekunder diperoleh dari KPKNL Manado terdiri atas.

1. Salinan Buku Penjualan; Dari sumber tersebut diperoleh data jenis lelang, data hasil pelaksanaan lelang yang dicapai, serta data harga lelang.

2. Risalah lelang; Data yang diperoleh dari risalah lelang meliputi harga lelang, nilai limit dan harga likuidasi, dan lokasi/alamat objek hak tanggungan. Risalah lelang juga mencantumkan hasil yang diperoleh dari setiap pelaksanaan lelang, apakah itu laku terjual atau tidak laku terjual, serta harga lelang yang terbentuk.

Data tersebut diperoleh dari Kantor Pelayanan Kekayaan Negara dan Lelang (KPKNL) Manado. Jenis data yang digunakan dalam penelitian ini adalah data cross section. Data primer adalah data jarak objek lelang terhadap pusat kota/CBD dan data lebar jalan di depan objek lelang. Jumlah sampel yang diambil dalam penelitian ini berjumlah 63 risalah lelang yang terdiri dari 16 risalah lelang yang laku dan 47 risalah lelang tidak ada peminat.

\section{Tahapan Penelitian} berikut ini.

Penelitian ini dilakukan dalam beberapa tahap yang meliputi langkah-langkah

1. Mengumpulkan data lelang eksekusi hak tanggungan yang telah dilaksanakan pada tahun 2015 sampai dengan September 2016 dengan objek lelang yang berada di Kota Manado. Jumlah data yang diobservasi adalah 1.323 risalah lelang. Data ini kemudian menjadi populasi yang digunakan dalam penelitian ini.

2. Dengan menggunakan teknik purposive sampling (sampel bertujuan) diambil sampel sebanyak 63 sampel risalah lelang

3. Dari sampel data yang diambil diperoleh informasi apakah objek lelang laku terjual atau tidak laku terjual, harga lelang yang terbentuk, nilai limit dan nilai likuidasi, dan lokasi/alamat objek lelang hak tanggungan

4. Untuk data jarak objek lelang terhadap pusat kota/CBD dan data lebar jalan di depan objek lelang dilakukan observasi lapangan dan dengan bantuan fasilitas ruler pada software "Google Earth".

5. Data-data yang sudah diperoleh disimpan dalam format microsoft exel. Kemudian data diolah dengan menggunakan software eviews 8.0 menggunakan metode regresi binary model logit.

6. Dari hasil pengolahan data dimaksud dilakukan uji estimasi dengan uji ekonomika, uji statistika dan uji ekonometrika dan selanjutnya membuat interpretasi hasil regresi.

\section{Metode Analisis deskriptif}

Analisis deskriptif digunakan dalam penelitian ini untuk mengkaji besarnya nilai rata-rata (mean), nilai tengah (median), nilai tertinggi (maximum), nilai terendah (minimum), dan standar deviasi dari variabel dependen hasil lelang dan variabel-variabel independen berupa aksesibilitas, deviasi nilai limit dan nilai likuidasi, lokasi, dan dummy kondisi kekosongan property.

\section{Metode Analisis regresi berganda binary model logit}

Keberhasilan lelang properti riil pada lelang eksekusi hak tanggungan di KPKNL Manado sebagai variabel dependen bersifat kualitatif dan dikotomis yaitu keberhasilan 
laku terjual atau tidak laku terjual. Model yang tepat untuk regresi dengan variabel dependen (Y) bersifat kualitatif atau binari/dikotomis adalah model regresi dengan respon kualitatif atau dikenal dengan probability model. Model yang digunakan dalam penelitian ini adalah logit, di mana nilai prediksi Y terletak antara 0 sampai dengan 1.

Bentuk umum model logit dapat dirumuskan sebagai berikut (Kuncoro, 2001: 210).

$$
\mathbf{L i}=\log
$$

di mana: $\quad \mathrm{Li} \quad=$ Variabel dependen

$\mathrm{X} \quad=$ Variabel independen, yang digunakan sebagai penjelas $\mathrm{Li}$

$\mathrm{b}_{0} \quad=$ Intercept, titik potong garis regresi dengan sumbu vertikal

$\mathrm{b}_{1} . . \mathrm{b}_{3}=$ Slope, kemiringan garis regresi yang menunjukkan arah gerak dari Li.

Model logit ini membuat probabilitas tergantung dari variabel-variabel yang diobservasi, yaitu $\mathrm{X}_{1}, \mathrm{X}_{2}$ dan seterusnya. Variabel-variabel ini dikalikan dengan koefisien $b_{1}, b_{2}$ dan seterusnya. Tujuan estimasi dengan model ini adalah menemukan nilai terbaik bagi masing-masing koefisien. Bila koefisien suatu variabel ternyata positif berarti semakin rendah nilai variabel tersebut berkaitan dengan semakin tinggi probabilitas bahwa $\mathrm{Y}=0$; dengan kata lain, semakin tinggi nilai suatu variabel berarti semakin tinggi probabilitas $\mathrm{Y}=1$.

Penelitian ini menggunakan model regresi sebagai berikut:

$$
\mathrm{HL}=b_{0}+b_{1} \mathrm{AKS}+b_{2} \mathrm{DLM}+b_{3} \mathrm{LOK}+b_{4} \mathrm{KOS}+\mathrm{e}
$$

di mana: $\quad$ HL $\quad=$ Hasil lelang Objek Lelang (1=laku terjual, $0=$ tidak laku terjual)

$b_{0} \quad=$ Intercept, yang menunjukkan tingkat konstanta HL

$b_{1} . . b_{4}=$ Slope, yang menunjukkan arah gerak dari HL dan koefisien variabel independen

AKS = Aksesibilitas/lebar jalan objek (meter)

DLM = Selisih antara nilai limit dengan nilai likuidasi (persen)

LOK = Lokasi Objek Lelang/jarak objek lelang dari CBD (kilometer)

KOS = Kondisi Kekosongan Objek Lelang (dummy $\mathrm{D}=0$ untuk objek lelang kosong, $\mathrm{D}=1$ untuk Objek Lelang tidak kosong)

e $\quad=$ Error Term

Proses analisis data dilakukan dengan program Eviews 8.0 dengan menggunakan metode regresi berganda model logit.

\section{HASIL PENELITIAN DAN PEMBAHASAN}

\section{Analisis Deskriptif Variabel-Variabel Dalam Penelitian}

Variabel kualitatif dalam penelitian ini adalah variabel dependen hasil lelang (HL) dan variabel independen kondisi kekosongan objek lelang (KOS) pada lelang hak tanggungan di KPKNL Manado. Satuan ukur dari variabel hasil lelang adalah 1 untuk lelang yang laku dan 0 untuk lelang yang tidak laku. Dari 63 sampel terdapat 16 lelang yang laku dan 47 lelang yang tidak laku. Satuan ukur dari variabel kondisi kekosongan objek lelang adalah 1 untuk objek lelang yang berpenghuni dan 0 untuk objek lelang yang tidak berpenghuni. Dari sampel yang diambil 34 objek lelang dalam kondisi berpenghuni dan 29 objek lelang yang kosong. Statistik deskriptif dari kedua variabel ini dapat dilihat pada tabel berikut: 
Tabel 1

Analisis Deskriptif Variabel Kualitatif Variabel Hasil Lelang dan Kondisi

Kekosongan

\begin{tabular}{|c|c|c|c|c|}
\hline \multirow{2}{*}{ Uraian } & \multicolumn{2}{|c|}{ Hasil Lelang (HL) } & \multicolumn{2}{|c|}{ Kondisi Kekosongan (KOS) } \\
\hline & Jumlah & $\%$ & Jumlah & $\%$ \\
\hline $\mathrm{D}=1$ & 16 & 25 & 34 & 54 \\
\hline $\mathrm{D}=0$ & 47 & 75 & 29 & 46 \\
\hline
\end{tabular}

Sumber: KPKNL Manado, Risalah Lelang, 2015- Sept. 2016 ( diolah)

Variabel-variabel independen selain kondisi kekosongan dalam penelitian ini merupakan variabel kuantitatif. Variabel independen aksesibilitas (AKS) yaitu lebar jalan di depan objek lelang hak tanggungan, satuan adalah meter (m). Statistik deskriptif aksesibilitas berupa lebar jalan di depan objek lelang meliputi rata-rata sebesar 8,34 m, median sebesar $7 \mathrm{~m}$, lebar jalan yang paling besar adalah $16 \mathrm{~m}$, lebar jalan yang paling kecil adalah 3,5 m, dan standar deviasi lebar jalan adalah sebesar 3,69 m. Variabel deviasi nilai limit dengan nilai likuidasi (DLM) adalah selisih dari nilai limit dengan nilai likuidasi dibandingkan dengan nilai likuidasi, satuan ukurnya adalah persentase. Statistik deskriptif dari variabel DLM rata-rata sebesar 31\%, median DLM sebesar 38\%, DLM terbesar sebesar 56\%, DLM terkecil sebesar 0\%, dan standar deviasi DLM sebesar $22 \%$.

Variabel Lokasi (LOK) adalah jarak objek lelang terhadap pusat kota/CBD, satuan adalah kilometer $(\mathrm{km})$. Statistik deskriptif dari lokasi objek lelang terhadap pusat kota/CBD meliputi rata-rata jarak sebesar $5.55 \mathrm{~km}$, median jarak sebesar $5,38 \mathrm{~km}$, jarak terjauh sebesar $14 \mathrm{~km}$, jarak terdekat sebesar $0 \mathrm{~km}$, dan standar deviasi jarak sebesar $3,72 \mathrm{~km}$. Statistik deskriptif dari variabel-variabel independen dapat dilihat pada tabel berikut:

Tabel 2

Analisis Deskriptif Variabel Kuantitatif Akesibilitas, Deviasi Limit dengan Likuidasi dan Lokasi

\begin{tabular}{|c|c|c|c|}
\hline Uraian & $\begin{array}{c}\text { Aksesibilitas } \\
\text { (AKS) }\end{array}$ & $\begin{array}{c}\text { Deviasi Limit dengan } \\
\text { Nilai Likuidasi (DLM) }\end{array}$ & $\begin{array}{c}\text { Lokasi } \\
\text { (LOK) }\end{array}$ \\
\hline Mean & 8,34 & 0,31 & 5,55 \\
\hline Median & 7,00 & 0,38 & 5,38 \\
\hline Maximum & 16,00 & 0,56 & 14 \\
\hline Minimum & 3,50 & 0,00 & 0 \\
\hline Standar Deviasi & 3,69 & 0,22 & 3,72 \\
\hline Observation & 63 & 63 & 63 \\
\hline
\end{tabular}

Sumber: KPKNL Manado, Risalah Lelang, 2015- Sept. 2016 (diolah)

\section{Analisis Hasil Regresi}

Untuk menganalisis faktor-faktor yang mempengaruhi hasil lelang hak tanggungan pada KPKNL Manado, digunakan alat analisis regresi berganda binary model logit, dengan menggunakan program Eviews 8.0 diperoleh hasil regresi metode binary logit sebagaimana tersaji pada Gambar berikut ini.

\section{Gambar 2}

\section{Hasil Regresi Metode Binary Logit}


Date: $02 / 21 / 17$ Time: 20:45

Sample: 163

Included observations: 63

Convergence achieved after 6 iterations

Covariance matrix computed using second derivatives

\begin{tabular}{crrrr}
\hline \hline \multicolumn{1}{c}{ Variabel } & Coefficient & Std. Error & z-Statistic & Prob. \\
\hline \hline AKS & 1.163966 & 1.626080 & 0.715811 & 0.4741 \\
DLM & 0.355262 & 0.168811 & 2.104497 & 0.0353 \\
LOK & -0.064288 & 0.030893 & -2.080986 & 0.0374 \\
KOS & -0.544283 & 0.255260 & -2.132271 & 0.0330 \\
& -4.927519 & 1.627813 & -3.027079 & 0.0025 \\
\hline \hline McFadden R-squared & 0.673936 & Mean dependent var & 0.253968 \\
S.D. dependent var & 0.438776 & S.E. of regression & 0.250176 \\
Akaike info criterion & 0.528260 & Sum squared resid & 3.630117 \\
Schwarz criterion & 0.698351 & Log likelihood & -11.64020 \\
Hannan-Quinn criter. & 0.595158 & Deviance & 23.28041 \\
Restr. deviance & 71.39826 & Restr. log likelihood & -35.69913 \\
LR statistic & 48.11785 & Avg. log likelihood & -0.184765 \\
Prob(LR statistic) & 0.000000 & & \\
\hline \hline Obs with Dep=0 & 47 & Total obs & 6 \\
Obs with Dep=1 & 16 & & \\
\hline \hline
\end{tabular}

Sumber: KPKNL Manado, Risalah Lelang, 2015- Sept. 2016 (diolah)

Sebelum melakukan interpretasi dan analisis lebih lanjut, untuk mengetahui baik tidaknya model regresi berganda maka perlu dilakukan pengujian. Dalam hal ini pengujian dilakukan dengan menggunakan 3 uji kriteria, yaitu uji kriteria ekonomika, uji kriteria statistika, dan uji kriteria ekonometrika dengan menguji asumsi regresi klasik(untuk model logit tidak dilakukan uji normalitas dan uji heteroskedastisitas).

\section{Uji Kriteria Ekonomika.}

Uji ini menyangkut masalah tanda dan intensitas hubungan ekonomi yang diteliti, yaitu dengan cara membandingkan kesesuian tanda di antara parameter estimasi dengan prinsip-prinsip teori ekonomi. Uji kriteria ekonomika digunakan untuk memutuskan seberapa jauh hasil estimasi dapat diartikan secara teoritis dan logis. Jika tanda koefisien parameter regresi sesuai dengan teori ekonomi maka parameter tersebut telah lolos dari uji tanda. Uji kriteria ekonomika berdasarkan regresi binari model logit pada faktor-faktor yang mempengaruhi hasil lelang adalah sebagai berikut.

\section{Tabel 3}

Hasil Uji Kriteria Ekonomika

\begin{tabular}{|c|c|c|c|}
\hline Variabel independen & Arah Hubungan & Hipotesis & Kesimpulan \\
\hline Aksesibilitas (AKS) & Positif & Positif & Sesuai \\
\hline Deviasi Nilai Limit dan Likuidasi (DLM) & Negatif & Negatif & Sesuai \\
\hline Lokasi (LOK) & Negatif & Negatif & Sesuai \\
\hline Kondisi Kekosongan (KOS) & Negatif & Negatif & Sesuai \\
\hline
\end{tabular}

Sumber: KPKNL Manado, Hasil Regresi Metode Binary Logit Risalah Lelang(diolah)

Hasil regresi menunjukkan arah atau tanda koefisien variabel aksesibilitas objek lelang (AKS) adalah positif $(+0,355)$ sehingga mempunyai hubungan yang positif terhadap hasil lelang. Hal ini sesuai dengan teori Fanning et. al. (1994: 59) yang 
menyatakan bahwa aksesibilitas objek lelang yang semakin baik lebih diminati dan oleh karenanya akan meningkatkan probabilitas terjualnya objek lelang dimaksud. Hasil penelitian Asabere dan Huffman (1992), Setiawan(2004), Novrizal (2007), Lestari(2009) dan Sutarmin(2012) juga menunjukkan bahwa aksesibilitas berupa lebar jalan berpengaruh positif terhadap probabilitas keberhasilan lelang.

Koefisien variabel deviasi nilai limit dengan nilai likuidasi (DLM) adalah negatif $(-0,064)$ sehingga mempunyai hubungan yang negatif terhadap hasil lelang. Nilai limit yang semakin tinggi akan meningkatkan harga jual, tetapi akan menurunkan keberhasilan lelang. Hal ini sesuai dengan penelitian McAcfee dan Vincent (1992), Deboer, Conrad, McNamara(1992). Hasil penelitian Setiawan (2005), Amdar(2012) dan Sahara(2013) juga menunjukkan bahwa deviasi nilai limit dengan nilai likuidasi berpengaruh negatif terhadap probabilitas keberhasilan lelang.

Koefisien variabel lokasi(LOK) menunjukkan arah atau tanda negative (-0.54). Lokasi atau jarak objek lelang terhadap pusat kota/Central Bussines Distrik (CBD) menunjukkan arah atau tanda negatif menunjukkan bahwa semakin jauh jarak objek lelang dengan pusat kota/CBD, maka probabilitasnya untuk laku akan semakin kecil. Teori lokasi menyatakan bahwa nilai suatu properti dipengaruhi oleh kedekatan properti dengan pusat kota/CBD. Hal ini sejalan dengan yang dikemukakan oleh Hidayati dan Harjanto (2003: 22). Hasil penelitian Mayer (1998), Dotzour, Moorhead dan Winkler (1998), Allen dan Swisher (2000), Ong, Lust, dan Mak (2005), Lestari (2009), dan Sahara (2012) juga menunjukkan bahwa jarak dari pusat kegiatan ekonomi berpengaruh secara negatif terhadap hasil lelang.

Koefisien varibel kondisi kekosongan objek lelang(KOS) menunjukkan arah dan tanda negatif (-4.93) yang berarti mempunyai hubungan negatif dengan keberhasilan lelang. Hal ini sudah sesuai dengan penelitian yang dilakukan oleh Ong, Lusht dan Mak (2004) dan Setiawan (2005) bahwa real property yang kosong pada saat pelaksanaan lelang atau tidak ditempati baik oleh debitor maupun pihak ketiga akan lebih diminati oleh calon pembeli lelang dan akan berpengaruh terhadap probabilitas terjualnya real property tersebut melalui lelang.

\section{Uji Kriteria Statistik.}

Uji kriteria statistika adalah uji yang dilakukan secara statistika. Pengujian ini meliputi pengujian koefisien regresi secara individu, pengujian koefisien regresi secara bersama-sama, dan uji kelayakan model regresi. Pengujian pengaruh secara individu dilakukan untuk mengestimasi pengaruh masing-masing variabel independen terhadap variabel dependen. Dengan $\alpha$ (level of significance) $=5 \%$, apabila probabilitas (prob.)>0,05, maka variabel independen tidak berpengaruh. Sebaliknya apabila probabilitas (prob.) $₫, 05$, maka variabel independen berpengaruh. Hasil pengujian pengaruh secara individu masing-masing variabel tersaji dalam Tabel berikut:

Tabel 4

Hasil Pengujian Secara Individu

\begin{tabular}{|c|r|r|r|c|}
\hline Variabel & \multicolumn{1}{|c|}{ Koefisien } & Z-Statistik & \multicolumn{1}{c|}{ Prob. } & Kesimpulan \\
\hline C & 1.163966 & 0.715811 & 0.4741 & Tidak Signifikan \\
\hline AKS & 0.355262 & 2.104497 & 0.0353 & Signifikan \\
\hline DLM & -0.064288 & -2.080986 & 0.0374 & Signifikan \\
\hline LOK & -0.544283 & -2.132271 & 0.0330 & Signifikan \\
\hline KOS & -4.927519 & -3.027079 & 0.0025 & Signifikan \\
\hline
\end{tabular}

Sumber: KPKNL Manado, Hasil Regresi Metode Binary Logit Risalah Lelang(diolah)

Tabel di atas menunjukkan bahwa variabel independen aksesibilitas (AKS) 
dengan nilai probabilitas 0.0355, maka variabel aksesibilitas (AKS) berpengaruh signifikan terhadap keberhasilan lelang. Variabel independen deviasi nilai limit dengan nilai likuidasi (DLM) dengan nilai probabilitas 0.0374, maka variabel deviasi nilai limit dengan nilai likuidasi (DLM) berpengaruh signifikan terhadap keberhasilan lelang. Variabel independen lokasi (LOK) dengan nilai probabilitas 0.0330, maka variabel lokasi (LOK) berpengaruh signifikan terhadap keberhasilan lelang. Variabel independen kondisi kekosongan objek lelang (KOS) dengan nilai probabilitas 0.0025, maka variabel kondisi kekosongan objek lelang (KOS) berpengaruh signifikan terhadap keberhasilan lelang.

Pengujian pengaruh secara bersama-sama dilakukan untuk mengetahui pengaruh variabel independen secara bersama-sama terhadap variabel dependen. Apabila probabilitas (LR stat) dari model $>0,05$, maka varibel independen secara bersama-sama tidak berpengaruh. Sebaliknya apabila probabilitas (LR stat) dari model $₫, 05$, maka variabel independen secara bersama-sama berpengaruh. Hasil regresi model logit menunjukkan bahwa nilai probabilitas (LR stat) dari model adalah sebesar 0,000000 yang berarti lebih kecil dari 0,05. Hal ini berarti bahwa keempat variabel independen, yaitu aksesibilitas (AKS), deviasi nilai limit dengan nilai likuidasi (DLM), lokasi (LOK) dan kondisi kekosongan objek lelang (KOS) secara bersama-sama berpengaruh signifikan terhadap variabel dependen hasil lelang (HL) di KPKNL Manado.

Tabel.5

Hasil Pengujian Secara Bersama-sama

\begin{tabular}{|c|c|c|c|}
\hline Model & df & LR Statistic & Probabilitas \\
\hline Logit & 4 & 48,11785 & 0,000000 \\
\hline
\end{tabular}

Sumber: KPKNL Manado, Hasil Regresi Metode Binary Logit Risalah Lelang(diolah)

Pengujian kelayakan model (goodness of fit) dilakukan untuk mengetahui kemampuan variabel independen menerangkan variabel dependen. Berdasarkan hasil regresi model logit diketahui bahwa nilai Mcfadden R-squared adalah sebesar 0,673936 yaitu bahwa kemampuan variabel independen menerangkan variabel dependen adalah sebesar 67,39 persen. Tetapi menurut Thomas (1997: 475) nilai Mcfadden $R$ Squared tidak cocok untuk digunakan dalam pengujian kelayakan model. Ukuran goodness of fit dapat dilihat dari daya prediksi model tersebut yaitu besarnya kemampuan model memprediksi dengan benar dari jumlah data yang diobservasi atau besarnya Count $R$ Squared dengan rumus (Gujarati, 2003: 606):

$$
\text { Count } R^{2}=\frac{\text { number of correct prediction }}{\text { total number of observation }}
$$


Ukuran goodness of fit juga dapat dinyatakan dalam persentase prediksi yang benar dari model (Wooldridge, 2000: 536).

Dengan program eviews 8.0, hasil prediksi dapat dilihat pada expectation prediction-table (Gambar 2).

\section{Gambar 3}

\section{Expectation Prediction Table}

Expectation-Prediction Evaluation for Binary Specification Equation: UNTITLED

Date: 02/21/17 Time: 20:53

Success cutoff: $\mathrm{C}=0.5$

\begin{tabular}{|c|c|c|c|c|c|c|}
\hline & \multicolumn{3}{|c|}{ Estimated Equation } & \multicolumn{3}{|c|}{ Constant Probability } \\
\hline & Dep $=0$ & Dep=1 & Total & Dep $=0$ & Dep $=1$ & Total \\
\hline$P(\operatorname{Dep}=1)<=C$ & 45 & 2 & 47 & 47 & 16 & 63 \\
\hline$P(D e p=1)>C$ & 2 & 14 & 16 & 0 & 0 & 0 \\
\hline Total & 47 & 16 & 63 & 47 & 16 & 63 \\
\hline Correct & 45 & 14 & 59 & 47 & 0 & 47 \\
\hline$\%$ Correct & 95.74 & 87.50 & 93.65 & 100.00 & 0.00 & 74.60 \\
\hline$\%$ Incorrect & 4.26 & 12.50 & 6.35 & 0.00 & 100.00 & 25.40 \\
\hline Total Gain* & -4.26 & 87.50 & 19.05 & & & \\
\hline \multirow[t]{3}{*}{ Percent Gain** } & NA & 87.50 & 75.00 & & & \\
\hline & \multicolumn{3}{|c|}{ Estimated Equation } & \multicolumn{3}{|c|}{ Constant Probability } \\
\hline & $\mathrm{Dep}=0$ & $\mathrm{Dep}=1$ & Total & $\mathrm{Dep}=0$ & $\mathrm{Dep}=1$ & Total \\
\hline$E(\#$ of $D e p=0)$ & 43.42 & 3.58 & 47.00 & 35.06 & 11.94 & 47.00 \\
\hline$E(\#$ of $D e p=1)$ & 3.58 & 12.42 & 16.00 & 11.94 & 4.06 & 16.00 \\
\hline Total & 47.00 & 16.00 & 63.00 & 47.00 & 16.00 & 63.00 \\
\hline Correct & 43.42 & 12.42 & 55.84 & 35.06 & 4.06 & 39.13 \\
\hline$\%$ Correct & 92.38 & 77.62 & 88.63 & 74.60 & 25.40 & 62.11 \\
\hline$\%$ Incorrect & 7.62 & 22.38 & 11.37 & 25.40 & 74.60 & 37.89 \\
\hline Total Gain* & 17.78 & 52.23 & 26.53 & & & \\
\hline Percent Gain ${ }^{* *}$ & 70.01 & 70.01 & 70.01 & & & \\
\hline
\end{tabular}

${ }^{*}$ Change in "\% Correct" from default (constant probability) specification

${ }^{* *}$ Percent of incorrect (default) prediction corrected by equation

Sumber: KPKNL Manado, Hasil Regresi Metode Binary Logit Risalah Lelang(diolah)

Gambar diatas menunjukkan model ini mampu memprediksi benar sebanyak 59 dari 63 objek lelang dengan kesalahan 4 kali sehingga Count $R$ Squared adalah 59:63 atau sama dengan 93,65 \% yang mempunyai arti bahwa kemampuan variabel independen menerangkan variabel dependen adalah sebesar 93,65 persen sehingga model ini layak untuk digunakan.

\section{Uji Kriteria Ekonometrika}

Uji kriteria ekonometrika atau disebut juga uji asumsi klasik berupa uji multikolinieritas yang bertujuan untuk mengetahui hubungan linier antar variabel independen dalam suatu model regresi. Pada tabel 6 dibawah terlihat korelasi antar variabel independen menunjukkan bahwa multikolinieritas yang terjadi namun berderajat rendah, karena masih di bawah 0,8 sehingga bisa diabaikan (Gujarati, 2003: 359), dan model ini sudah memenuhi asumsi klasik. 
Tabel 6

Korelasi Antar Variabel Independen

\begin{tabular}{|l|r|r|r|r|}
\hline Variabel & \multicolumn{1}{|c|}{ AKS } & \multicolumn{1}{|c|}{ DLM } & \multicolumn{1}{c|}{ KOS } & \multicolumn{1}{c|}{ LOK } \\
\hline AKS & 1 & -0.27034 & -0.194265 & -0.213826 \\
\hline DLM & -0.270340 & 1 & 0.281596 & 0.144546 \\
\hline KOS & -0.194265 & 0.281596 & 1 & 0.249794 \\
\hline LOK & -0.213826 & 0.144546 & 0.249794 & 1 \\
\hline
\end{tabular}

Sumber: KPKNL Manado, Hasil Regresi Metode Binary Logit Risalah Lelang(diolah)

\section{Pembahasan}

Hasil lelang yang diukur dengan laku terjual dan tidak laku terjual objek lelang dalam pelelangan dipengaruhi secara signifikan oleh faktor aksesibilitas, deviasi nilai limit dengan nilai likuidasi, lokasi objek lelang dan kondisi kekosongan objek lelang. Berdasarkan hasil analisis regresi model logit, estimasi model persamaan dalam penelitian ini dapat dirumuskan sebagai berikut:

$\mathrm{Pi}$

$$
\begin{aligned}
& \mathrm{Li}=\log -{ }_{1-\mathrm{Pi}}=1,164+0,355 \mathrm{AKS}-0,064 \mathrm{DLM}-0,544 \mathrm{LOK}-4,928 \mathrm{KOS} \\
& \text { z-statistik } \quad(0,716) \quad(2,104) \quad(-2.081) \quad(-2,132) \quad(-3,027)
\end{aligned}
$$

\section{$\mathrm{Pi}$}

McFadden R Square $=0,6739$

\section{: Odds Ratio \\ 1- P1}

Dalam regresi dengan metode binary model logit makan nilai koefesien masingmasing varibel tidak dapat langsung di interpretasikan namun melalui rasio peluang (odds ratio). Odds ratio merupakan ukuran resiko atau kecendrungan untuk keberhasilan atau tidak berhasilnya antara satu variabel dengan variabel lainnya. Nilai odds ratio dihasilkan dengan rumus e pangkat koefesien varibel ( $\left.\mathrm{e}^{\mathrm{b} 0, \mathrm{~b} 1, \mathrm{~b} 1, \mathrm{~b} 3, \mathrm{~b} 4}\right) \quad \mathrm{e}=$ 2,718. Hasil perhitungan odds ratio tersaji dalam tabel 4.8 berikut

\section{Tabel 7}

Odds Ratio

\begin{tabular}{|l|c|r|}
\hline \multicolumn{1}{|c|}{ Variabel } & Koefisien (b) & \multicolumn{1}{c|}{ Odds Ratio } \\
\hline Konstanta & 1,16397 & 1,42650 \\
\hline Aksesibilitas & 0,35526 & 0,93774 \\
\hline Deviasi limit dan likuidasi & $-0,06429$ & 0,58029 \\
\hline Lokasi & $-0,54428$ & 0,00725 \\
\hline Kondisi Kekosongan & $-4,92752$ & \\
\hline
\end{tabular}

Sumber: KPKNL Manado, Hasil Regresi Metode Binary Logit Risalah Lelang(diolah)

Pada tingkat keyakinan 95 persen, aksesibilitas objek lelang di Kota Manado secara statistik berpengaruh positif terhadap kemungkinan berhasilnya lelang. Artinya, ada perbedaan pengaruh jalan didepan objek lelang yang lebar dengan objek lelang yang jalan didepan objek lelang yang sempit terhadap probabilitas keberhasilan lelang. Nilai odds ratio 1,427 dari koefisien regresi variabel aksesibilitas sebesar 0,355 menunjukkan setiap peningkatan 1 meter lebar jalan didepan objek lelang maka probabilitas keberhasilan lelang akan meningkat menjadi 1,427 kali. Hal ini sesuai dengan hasil penelitian Asabere dan Huffman (1992), Setiawan(2004), Novrizal (2007), Lestari(2009) dan Sutarmin(2012) yang menyatakan aksesibilitas yang ditandai dengan lebar jalan akan berpengaruh signifikan terhadap harga dan probabilitas terjualnya objek lelang tersebut. 
Deviasi nilai limit dengan nilai likuidasi objek lelang di Kota Manado secara statistik berpengaruh negatif terhadap kemungkinan berhasilnya lelang pada tingkat keyakinan 95 persen. Artinya, ada perbedaan pengaruh objek lelang yang berbeda deviasi nilai limit dengan nilai likuidasinya terhadap probabilitas keberhasilan lelang. Nilai odds ratio 0,938 dari koefisien regresi variabel deviasi nilai limit dengan nilai likuidasi sebesar -0,0643 menunjukkan bahwa setiap peningkatan $1 \%$ deviasi nilai limit dengan nilai likuidasinya maka probabilitas keberhasilan lelang akan menurun menjadi 0,938 kali. Hal ini sesuai dengan hasil penelitian McAcfee dan Vincent (1992), Deboer, Conrad, McNamara(1992), Setiawan(2004), Amdar(2012) dan Sahara(2013) yang menyatakan peningkatan deviasi nilai limit dengan nilai likuidasi akan meningkatkan harga lelang namun akan menurunkan probabilitas keberhasilan lelang.

Lokasi objek lelang di Kota Manado secara statistik berpengaruh negatif terhadap keberhasilan lelang pada tingkat keyakinan 95 persen. Artinya, ada perbedaan pengaruh objek lelang yang berlokasi di wilayah pusat kota yang dekat dengan CBD dengan objek lelang yang berlokasi di pinggiran kota yang jauh dari CBD terhadap probabilitas keberhasilan lelang. Nilai odds ratio 0,581 dari koefisien regresi variabel lokasi sebesar -0,544 menunjukkan setiap kenaikan jarak $1 \mathrm{~km}$ dari pusat kota/CBD maka probabilitas keberhasilan lelang berupa terjualnya obyek lelang akan menurun menjadi sebesar 0,581 kali. Hal ini sesuai dengan hasil penelitian Mayer (1998), Dotzour, Moorhead dan Winkler (1998), Allen dan Swisher (2000), Ong, Lust, dan Mak (2005), Lestari (2009), dan Sahara (2012) yang menyatakan jarak objek lelang ke pusat kota/CBD mempunyai pengaruh negatif terhadap keberhasilan lelang.

Variabel dummy kondisi kekosongan objek lelang di Kota Manado secara statistik berpengaruh negatif terhadap keberhasilan lelang pada tingkat keyakinan 95 persen. Probabilitas terjualnya objek lelang yang kosong lebih besar dibandingkan probabilitas terjualnya objek lelang dalam kondisi di huni. Nilai odds ratio 0,007 dari koefisien regresi kondisi kekosongan sebesar -4,928 menunjukkan kecenderungan keberhasilan lelang berupa terjualnya obyek lelang yang berpenghuni adalah sebesar $0,007 \mathrm{kali}$ bila dibandingkan dengan penjualan dengan objek lelang yang tidak berpenghuni. Hal ini sesuai dengan hasil penelitian Ong, Lusht dan Mak (2004) dan Setiawan (2005) yang menyatakan bahwa real property yang kosong pada saat pelaksanaan lelang atau tidak ditempati baik oleh debitor maupun pihak ketiga akan lebih diminati oleh calon pembeli lelang dan akan berpengaruh terhadap probabilitas terjualnya real property tersebut melalui lelang.

\section{KESIMPULAN}

Berdasarkan analisis data dan pembahasan dapat diambil kesimpulan sebagai berikut.

1. Aksesibilitas (AKS) berupa lebar jalan menuju lokasi objek lelang berpengaruh terhadap keberhasilan lelang eksekusi hak tanggungan di KPKNL Manado;

2. Deviasi nilai limit dengan nilai likuidasi (DLM) objek lelang berupa persentase selisih nilai limit dengan nilai likuidasi berpengaruh terhadap keberhasilan lelang eksekusi hak tanggungan di KPKNL Manado;

3. Lokasi (LOK) objek lelang yang diukur dengan jarak objek lelang dengan pusat kota/CBD berpengaruh terhadap keberhasilan lelang eksekusi hak tanggungan di KPKNL Manado;

4. Kondisi kekosongan objek lelang yang merupakan variabel dummy, berpengaruh terhadap keberhasilan lelang eksekusi hak tanggungan di KPKNL Manado ;

5. Faktor aksesibilitas, deviasi antara nilai limit dengan nilai likuidasi, lokasi objek 
lelang serta kondisi kekosongan objek lelang secara bersama-sama mempengaruhi secara langsung keberhasilan lelang eksekusi hak tanggungan di KPKNL Manado.

\section{SARAN}

Berdasarkan hasil penelitian ini, beberapa saran hendak di sampaikan kepada beberapa pihak (stake holder).

1. Variabel independen aksesibilitas (AKS), deviasi antara nilai limit dengan nilai likuidasi (DLM), lokasi objek lelang (LOK) dan kondisi kekosongan objek lelang (KOS) berpengaruh terhadap keberhasilan lelang (HL) di KPKNL Manado, sehingga untuk setiap pelaksanaan lelang eksekusi hak tanggungan pihak kreditor dan KPKNL Manado perlu mempertimbangkan faktor-faktor tersebut agar probabilitas keberhasilan lelang (laku terjual) semakin tinggi. Dengan tingkat keberhasilan lelang yang semakin baik maka dapat mengurangi masalah yang dihadapi kreditor/perbankan (menurunkan tingkat kredit bermasalah/non performing loan) dan akan meningkatkan pendapatan kepada negara berupa bea lelang dan pajak penghasilan serta meningkatkan pemasukan kepada pemerintah daerah Kota Manado berupa Bea Perolehan Hak atas Tanah dan Bangunan (BPHTB).

2. Jika kondisi ideal seperti di atas tidak dapat diwujudkan maka dapat dilakukannya upaya yang lebih intensif dalam menarik sebanyak-banyaknya calon pembeli dengan mengintensifkan penyebarluasan pengumuman lelang ke berbagai segmen pasar.

3. Pihak perbankan selaku kreditur harus lebih berhati-hati dengan melakukan analisis terhadap barang jaminannya terutama untuk jaminan berupa tanah atau tanah dan bangunan.

4. Pihak perbankan selaku kreditur dan pemohon lelang sebaiknya tidak menetapkan harga limit yang tinggi dan mempunyai selisih yang besar dengan nilai likuidasi.

5. Perbankan selaku kreditur dan pemohon lelang juga disarankan untuk melakukan upaya - upaya persuasif untuk mengosongkan objek lelang terlebih dahulu seperti sudah diatur dalam akta perjanjian kredit sehingga bisa digunakan perbankan untuk mengosongkan objek jaminannya sebelum dijual melalui pelelangan.

\section{DAFTAR PUSTAKA}

Allen, M.T. dan J. Swisher, 2000, An Analysis of the Price formation Process at a HUD Auction, Journal of Real Estate Research, 20 (3), 279-98.

Amdar, Marwan, 2011, "Determinan Deviasi Harga Lelang Terhadap Nilai Limit (Studi Lelang Riil Properti Jaminan Utang di KPKNL Kendari Tahun 2008-2010)", Tesis S-2, PPS-UGM, Yogyakarta.

Appraisal Institute, 2001, The Appraisal of Real Estate, 12-th Edition, Chicago.

Arsyad. L., 1999. Pengantar Perencanaan dan Pembangunan Ekonomi Daerah, BPFE Yogyakarta.

Asabere, P.K. dan Huffman, F.E., 1992, Price Determinants and Foreclosed Urban Land, Urban Studies, 29 (5), 701-07.

Deboer, L., Conrad, J. dan McNamara, K., 1992, Property Tax Auction Sales, Land Economics, 5 (3), 72-82.

Departemen Keuangan RI, Peraturan Menteri Keuangan Nomor 72/PMK.06/2016 tentang Petunjuk Pelaksanaan Lelang.

Dotzour, M.G., Moorhead, E. dan Winkler, D.T., Auction on Residential Sales Prices in New Zealand, Journal of Real Estate Research, 1998, 16(1), 57-70.

Fanning, Stephen F., Terry V. Grissom dan Thomas D. Pearson, 1994, MarketAnalysis for Valuation Appraisals, Appraisal Institute, Illinois. 
Gujarati, Damodar N, 2003, Basic Econometrics, 4-th Edition, Mc Graw-Hill/Irwin, New York.

Hidayati dan Harjanto, 2003, Konsep dasar Penilaian Properti, BPFE, Yogyakarta.

Kuncoro, Mudrajad,2001, Metode Kuantitatif: Teori dan Aplikasi untuk Bisnis dan Ekonomi, Unit Penerbitan dan Percetakan AMP YKPN, Yogyakarta.

Lestari, Istina Setya, 2009, "Determinan Keberhasilan Lelang Eksekusi Hak Tanggungan Di Kantor Pelayanan Kekayaan Negara dan Lelang Semarang Tahun 2005-2008", Tesis S-2, PPS-UGM, Yogyakarta.

Mayer, C.J., 1995, A Model of Negotiated sales Applied to Real Estate Auctions, Journal of Urban Economics, 38 (1): 1-22.

McAfee, P. dan McMillan, J., 1987, Auctions with Stochastic Number of Bidders, Journal of Economics Theory, 43, 1-19.

McAfee, P. dan Vincent, D., 1992, Updating the Reserve Prices in Common Value Auctions, American Economic Review, 82 (2), 512-518.

McAfee, P., Quan, D., Vincent, D., 2002, How to set Minimum Acceptable Bids, with an Application to Real Estate Auctions, Journal of Industrial Economics, 50(4), 391-417.

Novrizal, 2007, "Faktor-faktor yang Mempengaruhi Keberhasilan Lelang Eksekusi Hak Tanggungan Pada KP2LN Bandung II", Tesis S-2, PPSUGM, Yogyakarta .

Ong, S.E., Lusht, K., Mak, C.Y., 2004, Factor Influencing Auction Outcomes: Bidder Turnout, Auction Houses and market Condition, Journal of Real Estate Research, 5 (3), 1-21.

Ong, S.E., 2005, Price Discovery in Real Estate Auctions: The Story of Unsuccessful Attempts , Journal of Real Estate Research, 8(2), 1-28.

Sekretariat Negara RI, Vendu Reglement/Peraturan Lelang, ordonansi 28 Februari 1908 stb 08-189.

Sekretariat Negara RI, Undang Undang Nomor 4 tahun 1996 tentang hak tanggungan Atas tanah Beserta Benda Benda yang Berkaitan dengan Tanah, Tambahan Lembaran Negara Nomor 3632.

Soeratno, dan Lincolin Arsyad, 2003, Metodologi Penelitian untuk Ekonomi dan Bisnis Edisi Revisi, UPP AMP YKPN, Yogyakarta.

Tarigan, R, 2004, Perencanaan Pembangunan Wilayah, PT Bumi Aksara, Jakarta

Todaro, M.P, 2003, Pembangunan Ekonomi Dunia Ketiga, Edisi Ke Delapan, Erlangga, Jakarta

Widarjono, Agus, 2007, Ekonometrika Teori dan Aplikasi Untuk Ekonomi dan Bisnis, Edisi Kedua, Ekonisia, Yogyakarta. 